Jurnal Abdimas Berdaya : Jurnal Pembelajaran, Pemberdayaan dan Pengabdian Masyarakat Volume 4 Nomor 01 Tahun 2021 e-ISSN: 2720 - 9768

\title{
Penerapan IoT Pada Proses Produksi Saos Dengan Sistem Less-Contact Didukung Database-Smart App Untuk UKM Sejahtera Sentosa
}

\author{
Application of IoT in Saos Production Process with Less-Contact System \\ Supported by Database-Smart App for Sejahtera Sentosa SME
}

\author{
Aripriharta $^{1}$, Agusta Rakhmat Taufani ${ }^{2}$, Irma Kartika Kusumaningrum ${ }^{3}$, \\ Satia Nur Maharani ${ }^{4}$, Adim Firmansah ${ }^{5}$ \\ 1,2,3,4,5 Universitas Negeri Malang \\ e-mail: ${ }^{1}$ aripriharta.ft@um.ac.id, ${ }^{2}$ agusta.rakhmat.ft@um.ac.id, \\ 3irma.kartika.fmipa@um.ac.id, ${ }^{4}$ satia.nur.fe@um.ac.id, ${ }^{5}$ adimfirmansah@gmail.com
}

\begin{abstract}
Abstrak: Pandemi Covid-19 hampir membuat banyak bisnis UKM gulung tikar Salah satu UKM yang terdampak pandemi Covid-19 adalah UKM Sejahtera Sentosa. Melalui skema pengabdian UKM Indonesia Bangkit 2020, Tim Pengabdian UM membangkitkan produktivitas UKM Sejahtera sentosa melalui teknologi TTG produksi saos tidak beresiko membawa COVID-19. Pengabdian ini juga bertujuan mempertahankan bisnis saos yang lesu akibat pandemi COVID-19. Implementasi TTG IoT akan memiliki sasaran yaitu (1) proses produksi memenuhi $90 \%$ less contact (2) stabilitas kontrol viskositas saos meningkat $100 \%$ persiklus produksinya, (3) biaya produksi ditekan $30 \%$. Pada Aspek Teknologi Pemasaran/Distribusi, penerapan TTG smart apps dapat menghasilkan luaran mitra berupa (1) omzet naik 30\%, (2) video promosi. Kegiatan ini dimulai dari wawancara ekslusif, desain dan implementasi TTG, pelatihan dan pendampingan, dan serah terima. Hasil implementasi TTG berjalan dengan baik dimana HMI dan aplikasi smartphone yang dikembangkan mampu melakukan sinkronisasi dengan baik. Pengabdian ini juga memberikan dampak ekonomi dan sosial berupa peningkatan omzet penjualan dan antusiasme masyarakat terhadap produk Deepika.
\end{abstract}

Kata Kunci: produksi, UKM, aplikasi smartphone, less-contact.

Abstract: The Covid-19 pandemic has almost brought many SME businesses out of business. One of the SMEs affected by the Covid-19 pandemic is Sejahtera Sentosa SME. Through the UKM Indonesia Bangkit 2020 scheme, the UM Service Team awakens the productivity of UKM Sejahtera Sentosa through the TTG technology, the production of sauce without the risk of carrying COVID-19. This service also aims to maintain the sluggish sauce business due to the COVID-19 pandemic. The implementation of TTG IoT have targets (1) the production process meets $90 \%$ less contact (2) the stability of the sauce viscosity control increases $100 \%$ per production cycle, (3) production costs are reduced by 30\%. In the Marketing / Distribution Technology Aspect, the application of TTG smart apps can produce output (1) turnover increaased up to 30\%, (2) promotional videos. This activity started with an exclusive interview, the design and implementation of the TTG, training and mentoring, and handover. The results of the TTG implementation went well where the HMI and smartphone applications developed were able to synchronize well. This service also has an economic and social impact in the form of increased sales turnover and public enthusiasm for Deepika's sauce.

Keywords: production, SME, smartphone application, less-contact. 


\section{A. Pendahuluan}

Pandemi Covid-19 hampir membuat banyak bisnis UKM gulung tikar (Awaloedin et al., 2020; Thaha, 2020). Hal tersebut memicu banyaknya penelitian dan pengabdian yang bertujuan untuk meningkatkan ketahanan dan keberlangsungan UKM selama masa pandemi Covid-19 (Komalasari et al., 2020; Sunardi, Nardi. Lesmana, Rosa. Kartono. Rudy. Hasbiyah, 2020). Mulai dari pelatihan manajemen usaha (Irawati et al., 2020; Rosmadi, 2020), pemasaran digital (Sugiarti et al., 2020; Zanuar Rifai \& Meiliana, 2020), hingga inovasi berupa pameran virtual (Budiyanto et al., 2020).

Salah satu UKM yang terdampak pandemi Covid-19 adalah UKM Sejahtera Sentosa. Berdasarkan wawancara eksklusif dengan founder UKM Sejahtera Sentosa, Bapak Handrian Thomas, ST (Gambar 1), penyebab utama penurunan omzet, antara lain: (1) kafe-kafe di kota Malang sebagai konsumen utama tutup selama PSBB; (2) masyarakat malang belum terbiasa mengkonsumsi roti sebagai makanan utama, sehingga konsumen umum tidak bertambah secara signifikan. Hal ini disikapi dengan sebuah inovasi dengan melakukan diversifikasi produk yang ekstrim, yaitu saos "Deepika". Deepika merupakan produk saos aneka rasa, mulai keju, balado, dan beberapa varian lain seperti pada Gambar 1 (Foto paling kiri).

Produk baru ini mendapat reaksi positif dari masyarakat umum. Omzet dari saos Deepika perlahan meningkat. Tetapi, proses produksinya masih dilakukan dengan semi otomatis. Konsumen yang mulai kritis dengan kualitas, rasa dan lebih dalam lagi ke proses pembuatan menyebabkan Founder UKM menjadi sangat terpojok, seperti dikutip dari wawancara terakhir dengan Founder UKM Sejahtera Sentosa (Foto pada Gambar 1). Kendala mitra dalam posisi ekonomi yang sulit untuk menambah investasi peralatan modern membuat founder khawatir akan biaya investasi dan mismatch dalam pengadaan peralatan produksinya. Mitra juga dihadapkan dengan beberapa masalah diantaranya (1) Bagaimana caranya agar produksi saos tidak beresiko membawa COVID- 19, (2) Bagaimana caranya agar bisnis saos tetap bertahan di masa COVID-19.
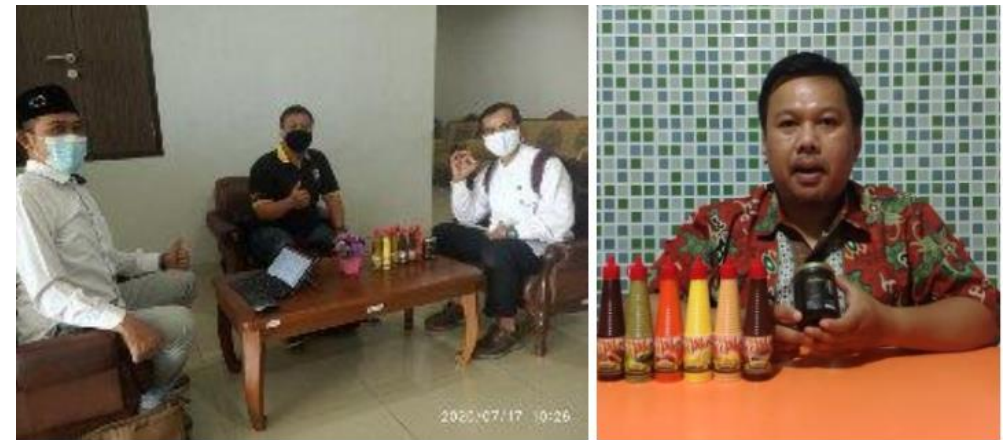

Gambar 1. Wawancara Eksklusif dengan Founder UKM Sejahtera Sentosa.

Pendemi Covid-19 memiliki kemampuan penyebaran yang cepat dan menimbulkan keresahan masyarakat (Ridlo et al., 2020; Sukur, 2020). UKM membutuhkan teknologi yang memungkinkan produksi dengan kontak operator seminimal mungkin untuk meningkatkan rasa kepercayaan masyarakat. Melalui skema 
pengabdian UKM Indonesia Bangkit 2020, Tim Pengabdian UM membangkitkan produktifitas UKM Sejahtera sentosa melalui teknologi TTG produksi saos tidak beresiko membawa COVID-19. Pengabdian ini juga bertujuan mempertahankan bisnis saos yang lesu akibat pandemi COVID-19. Implementasi TTG IoT akan memiliki sasaran (Gambar 2), yaitu: (1) proses produksi memenuhi 90\% less contact (2) stabilitas kontrol viskositas saos meningkat $100 \%$ persiklus produksinya, (3) biaya produksi ditekan $30 \%$. Kedua adalah Aspek Teknologi Pemasaran/Distribusi, dimana penerapan TTG smart apps dapat menghasilkan luaran mitra berupa: (1) omzet naik 30\%, (2) video promosi.

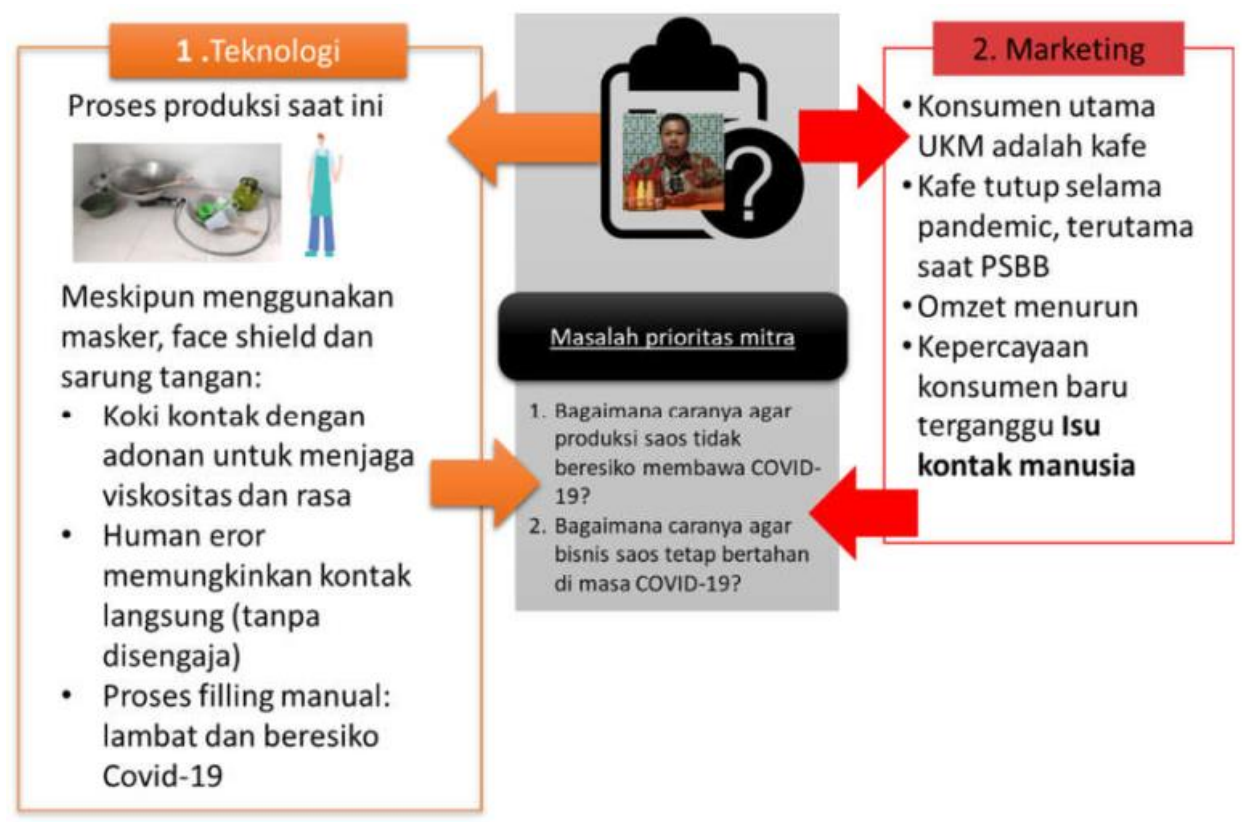

Gambar 2. Wawancara Eksklusif dengan Founder UKM Sejahtera Sentosa.

\section{B. Metode}

Kegiatan ini dimulai dari wawancara eksklusif, desain dan implementasi TTG, pelatihan dan pendampingan, serah terima, dan publikasi. Wawancara dilakukan untuk menggali permasalahan prioritas mitra dan menawarkan solusi praktis. Kedua adalah desain dan pembuatan serta uji coba TTG yang dilakukan di Laboratorium PLC TE FT UM dan Lab Kimia FMIPA UM. Implementasi TTG langsung di lokasi UKM sejahtera Sentosa di Kel. Purwantoro, Kec. Blimbing, Kota Malang, Jawa Timur. Pelatihan dan pendampingan dilakukan untuk memudahkan operator Mitra dalam menggunakan sistem (TTG) yang telah dikembangkan.

\section{Identifikasi kebutuhan}

Proses identifikasi kebutuhan dilakukan melalui wawancara eksklusif dengan Founder Mitra yang dilakukan dua kali. Pertama via telepon (Whatsapp) dan yang kedua dengan mengundang mitra ke LP2M UM. Wawancara terakhir dilakukan pada tanggal 28 Juli 2020 di Gedung Rektorat UM lantai 6. Hasil wawancara berupa JURNAL ABDIMAS BERDAYA: Volume 4 Nomor 01 Tahun 2021 
kesepakatan tentang masalah/kebutuhan prioritas mitra dalam dua aspek teknologi, yaitu proses produksi dan pemasaran.

\section{Desain/ perancangan}

TTG yang ditawarkan berdasarkan kebutuhan mitra ada dua, yaitu TTG IoT dan TTG database-smart app. TTG IoT di desain dengan beberapa langkah dimulai dari identifikasi masalah, peletakan router, pemilihan sensor dan aktuator, programming UI sampai ke integrasi ke mesin produksi. Jikalau saat implementasi terjadi kekeliruan atau setting yang kurang sesuai, maka dilakukan revisi/perbaikan. Selain IoT, kami juga menambahkan panel surya untuk sumber daya, sehingga UKM dapat menekan biaya produksi (listrik) perbulan untuk proses produksinya. TTG databasesmartapp dikembangkan dengan native language dan dukungan cloud.

\section{Pembuatan TTG}

TTG IoT dan Smart app dibuat di Laboratorium sistem kendali TE FT UM dengan kurun waktu 2-3 minggu. Pembuatan dibantu tukang,13 laboran dan mahasiswa dengan menerapkan protocol COVID-19. Prototype TTG IoT diuji coba di Lab TE FT UM dan Lab Kimia FMIPA UM. Proses uji coba diawasi penuh oleh tim dosen dan laboran pada masing-masing lab tersebut. TTG database-smart app diprogram oleh Dosen ahli informatika dna dibantu mahasiswa. Proses pembuatan TTG memerlukan alat dan bahan sebagai berikut: sensor temperatur, sensor viskositas, valve air, valve gas, router, node IoT, cloud database, AVOmeter, obeng, laptop, osciloscop, dan beberapa perlatan pertukangan.

\section{Pendampingan Operasional}

Pendampingan operasional tim terhadap mitra UKM dilakukan mulai tahap implementasi, dilanjutkan ke tahap pelatihan. Pada tahap pelatihan operator mitra akan dilatih menggunakan TTG IoT dan database-smartapp menggunakan buku panduan yang telah disediakan. Di sisi lain, pengawasan dan pendampingan operasional terhadap tim dilakukan oleh LP2M untuk menjaga transparansi dan keberhasilan kegiatan ini melalui desain operasional dan laporan kemajuan serta pertangung jawaban SPJ.

\section{Implementasi Teknologi}

Pada bagian desain telah disebutkan bahwa teknologi yang ditawarkan diterapkan langsung ke mesin produksi. TTG IoT sebagai core RI 4.0, dipasang pada mesin produksi untuk mengurangi kontak langsung antara operator dengan bahan saos. Sementara TTG smart app digunakan langsung pada smartphone pemilik UKM dan tim pemasarannya. Gambar 3 menunjukkan alur implementasi TTG. 


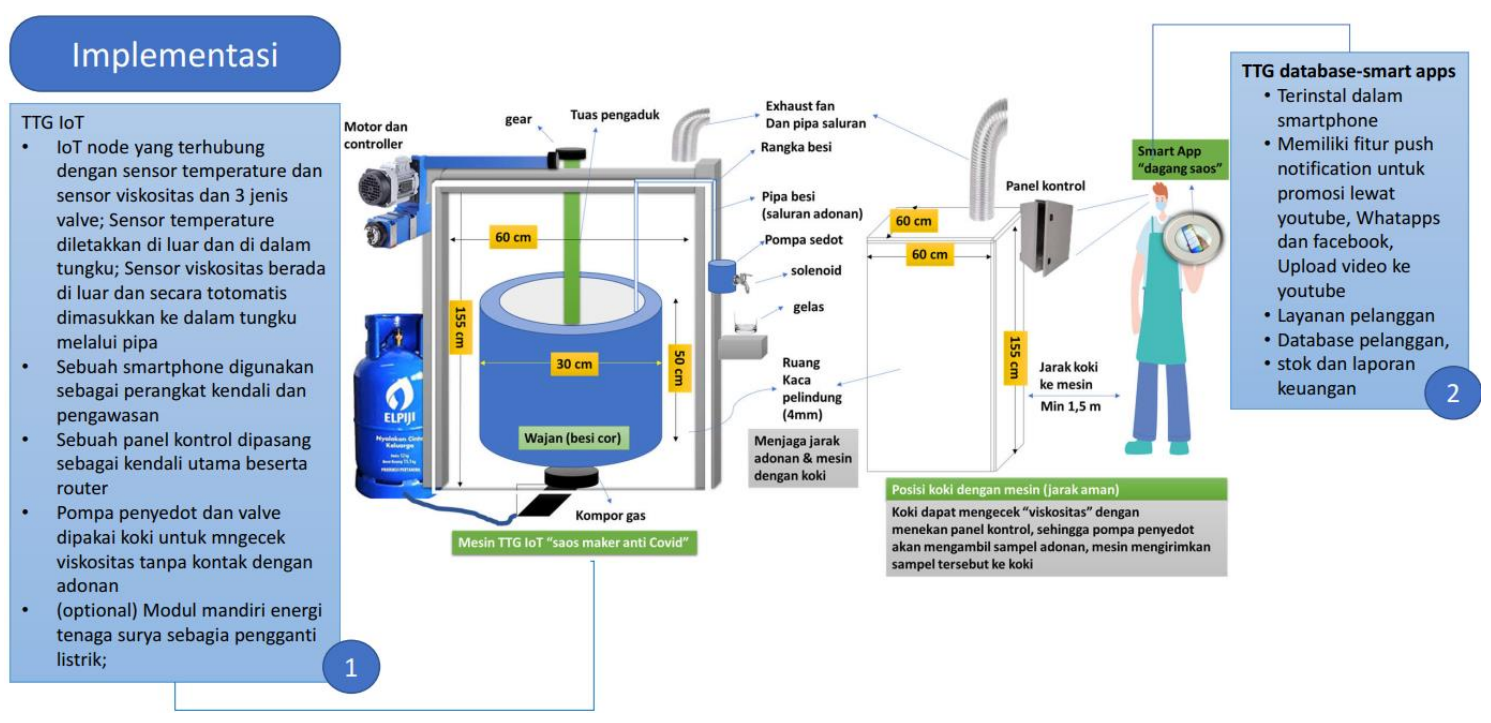

Gambar 3. Alur implementasi TTG

Target luaran kegiatan UKM indonesia bangkit ini ada dua, yaitu 2 buah TTG • Hardware: TTG IoT, berupa mesin produksi saos less-contact $\bullet$ Software: TTG database smart apps TTG IoT dan TTG database-smart app terintegrasi menjadi satu sistem. TTG IoT terdiri dari: IoT node yang terhubung dengan sensor temperatur dan sensor viskositas dan 3 jenis valve; Sensor temperature diletakkan di luar dan di dalam tungku; Senosr viskositas berada di luar dan secara totomatis dimasukkan ke dalam tungku dengan tangan buatan (pneumatic/motor servo); Sebuah smartphone digunakan sebagai perangkat kendali dan pengawasan; Modul mandiri energi tenaga surya sebagia pengganti listrik; dan Sebuah panel kontrol baru dipasang sebagai kendali utama beserta router IoT. Smart app diinstal dalam smartphone dengan fitur yang cukup lengkap, yakni integrasi dengan youtube, facebook dan Whatapps.

\section{Hasil dan Pembahasan}

1. Implementasi TTG

TTG dapat dikendalikan dari dua perangkat, yaitu melalui perangkat HMI yang diletakkan di area produksi atau melalui aplikasi smartphone. Gambar 4 menunjukkan tampilan layar HMI pada area produksi. HMI dilengkapi dengan tampilan grafik untuk menampilkan suhu pada beberapa titik TTG (S1-S4). Suhu tersebut diperbarui secara realtime oleh TTG. TTG mengirimkan data informasi suhu untuk disimpan di cloud database. Pada tampilan HMI terdapat tombol Power yang digunakan untuk mengaktifkan pompa saos pada TTG. Ketika diaktifkan, tombol power tersebut berubah warna menjadi hijau dan pompa saos aktif. Pompa saos aktif untuk menuangkan saos ke gelas uji. Pompa otomatis berhenti bekerja setelah selang beberapa waktu dan tombol power berubah menjadi warna hitam kembali. Fitur tersebut berguna untuk memantau kualitas saos saat proses produksi sehingga kualitas saos tetap terjaga meskipun dengan produksi less-contact. 

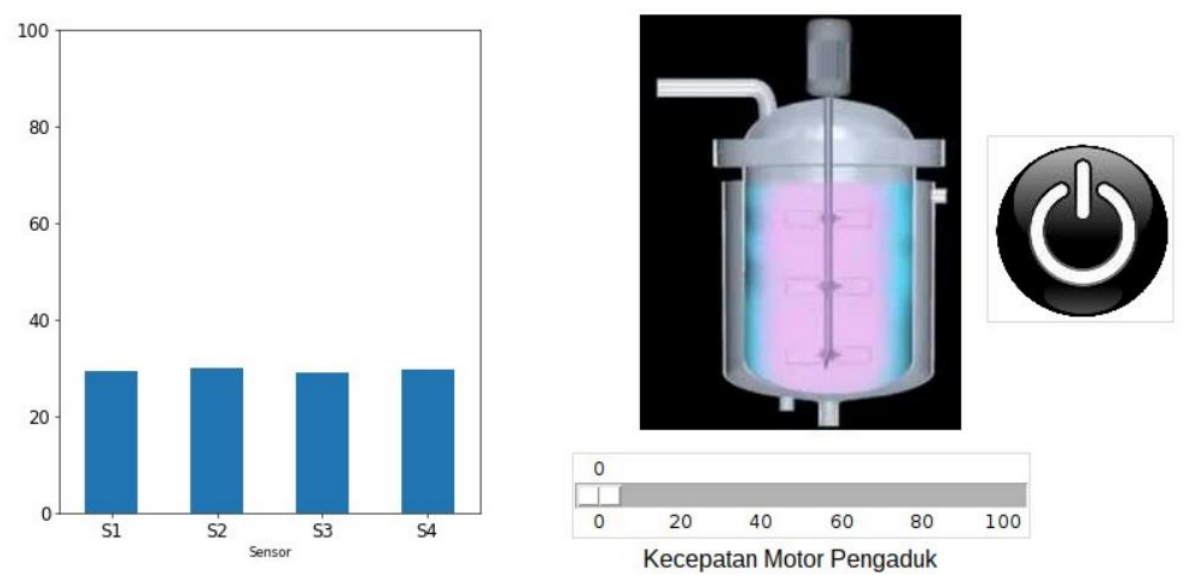

Gambar 4. Tampilan HMI

Pada tampilan HMI juga disediakan fitur untuk mengatur kecepatan motor pengaduk. Kecepatan yang disediakan bervariasi dari 0 hingga 100\%. Menurut Founder Mitra, fitur ini sangat membantu meningkatkan efisiensi dan kualitas produksi. Hal tersebut dikarenakan putaran yang terlalu pelan membuat saos lebih lama matang. Namun, pada beberapa periode proses produksi juga dibutuhkan kecepatan adukan yang pelan.

Fitur-fitur pada aplikasi smartphone mirip dengan HMI yang diletakkan pada TTG di area produksi. Perbedaannya terletak pada tombol di bagian kanan bawah untuk melihat buku panduan penggunaan. Fitur tersebut hanya disediakan di aplikasi smartphone. Secara simultan, aplikasi smartphone (Gambar 5) mengambil data pada cloud database dan menampilkannya. Suhu yang ditampilkan pada HMI juga ditampilkan pada aplikasi smartphone. HMI dan aplikasi smartphone secara otomatis mensinkronkan tampilan kecepatan motor dan tombol power. Jika tombol power pada HMI ditekan dan berubah menjadi warna hijau (pompa saos aktif), maka tampilan tombol power di aplikasi smartphone juga berubah menjadi hijau untuk menandakan bahwa pompa saos sedang aktif.

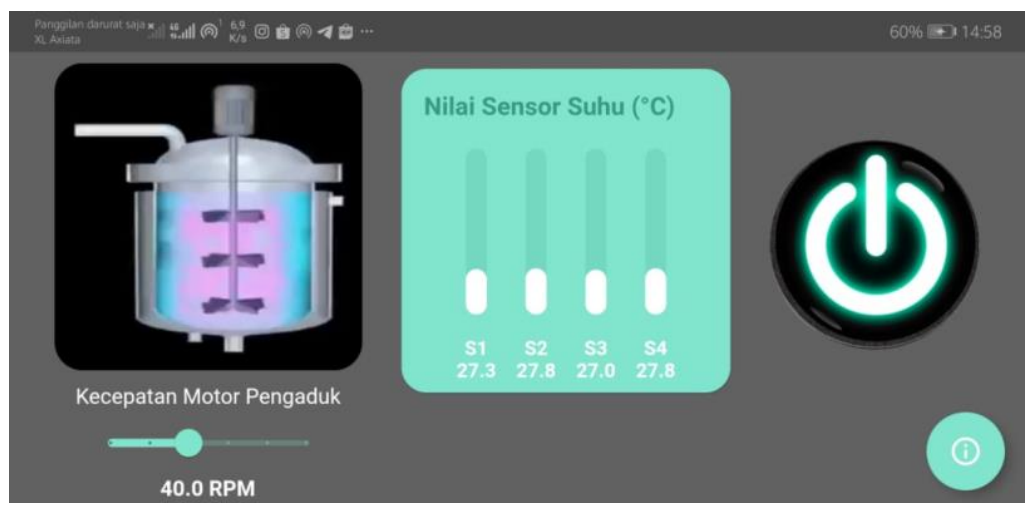

Gambar 5. Tampilan halaman kendali Smart app 
Hal tersebut juga berlaku pada tampilan kecepatan motor pengaduk. Jika kecepatan motor pengaduk diubah melalui HMI, maka kecepatan motor yang ditampilkan pada aplikasi smartphone juga ikut berubah, dan sebaliknya. Waktu sinkronisasi antara HMI dan aplikasi smartphone sangat cepat. Ketika dilakukan tes di area produksi, TTG berjalan dengan baik. Aplikasi smartphone dapat mengontrol TTG dari tempat yang jauh selama smartphone memiliki koneksi internet. Gambar 6 menunjukkan proses uji coba HMI dan aplikasi smartphone.

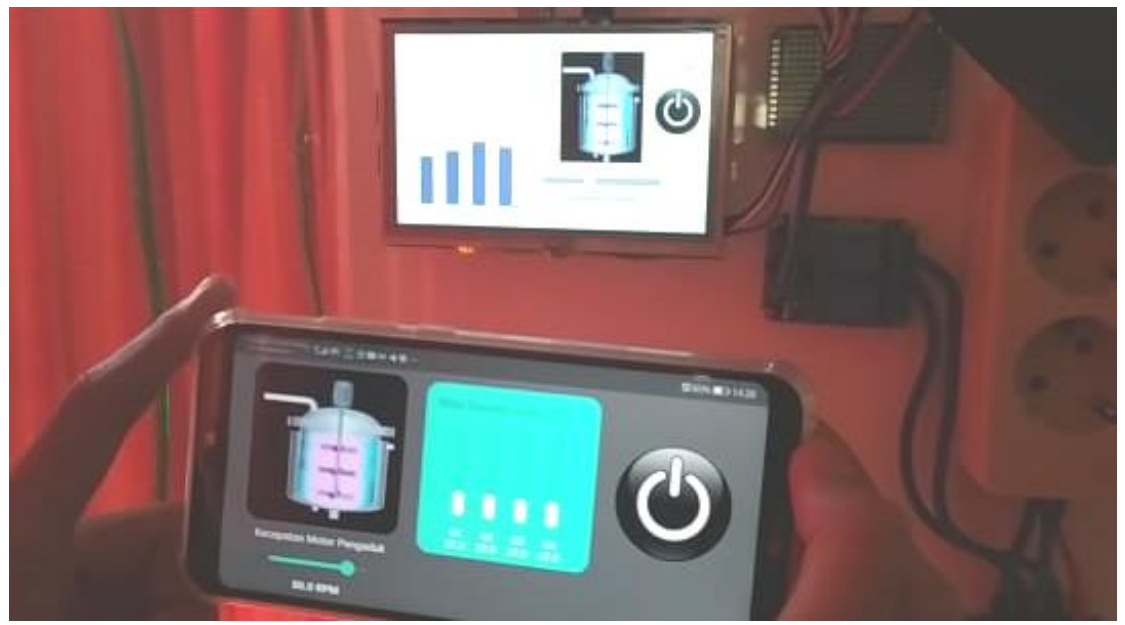

Gambar 6. Uji coba HMI dan aplikasi smartphone

2. Dampak Ekonomi dan Sosial

Manfaat kegiatan UKM Indonesia bangkit ini bagi mitra dapat ditinjau dari dua lingkup seperti Gambar 7. Pertama adalah aspek peningkatan kapasitas teknologi (proses produksi), dimana mitra implementasi TTG IoT akan menghasilkan luaran mitra berupa: (1) proses produksi memenuhi $90 \%$ less contact (2) stabilitas kontrol viskositas saos meningkat $100 \%$ persiklus produksinya, (3) biaya produksi ditekan $30 \%$. Kedua adalah Aspek Teknologi Pemasaran/Distribusi, dimana penerapan TTG smart apps dapat menghasilkan luaran mitra berupa: (1) omzet naik 30\%, (2) video promosi.

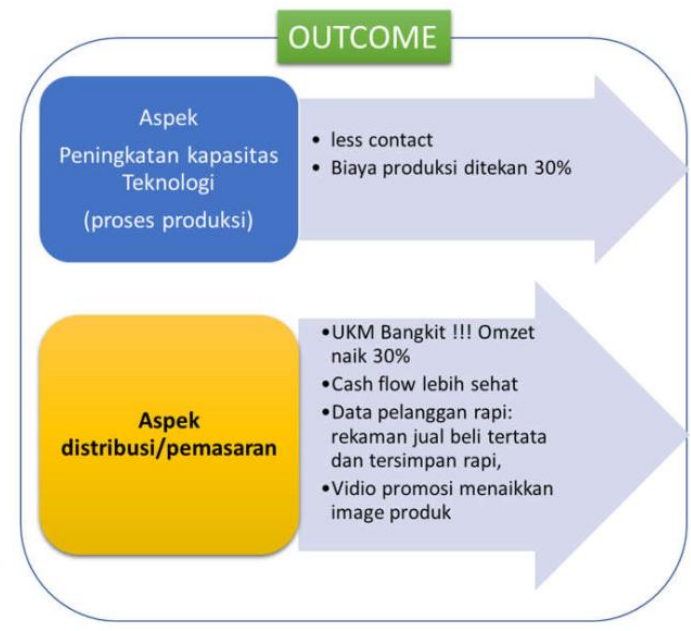

Gambar 7. Manfaat kegiatan 
Sementara itu dampak ekonominya dapat dilihat dari hasil implementasi digital marketing menggunakan TTG dagang saos yang terintegrasi dengan tokopedia, blibli dan media sosial. Gambar 8(a) memperlihatkan contoh testimoni 16 pembeli melalui Tokopedia UKM Mitra. Gambar 8(b) dan Gambar 8(c) masing-masing memperlihatkan omzet mitra selama bulan Oktober dan November 2020. Omzet masih di bawah 1 juta rupiah, tetapi ini tetap menunjukkan peningkakan yang berarti, karena sebelumnya mitra belum pernah menggunakan fasilitas digital marketing.

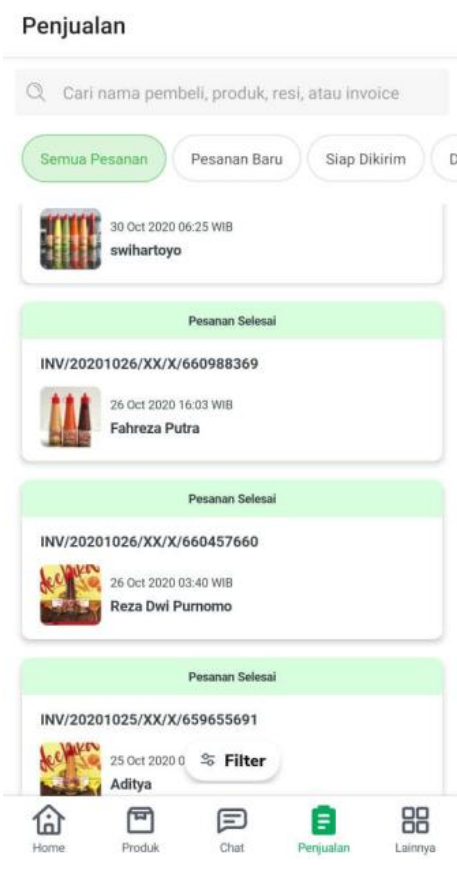

(a)

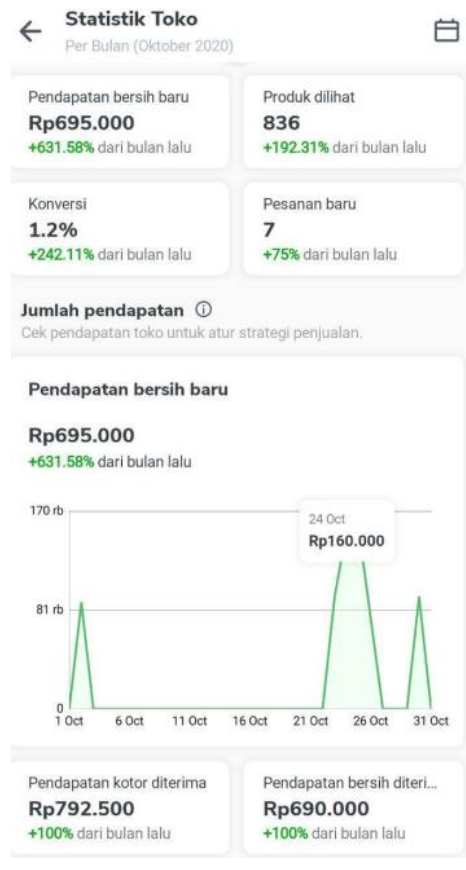

(b)

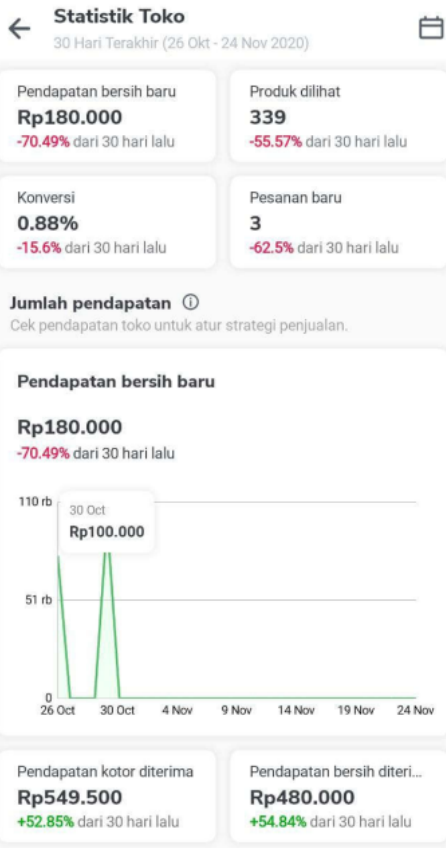

(c)

Gambar 8. Dampak ekonomi

Gambar 9 juga merupakan dampak sosial dari kegiatan ini. Pengusaha/pemilik UKM mendapat kesempatan untuk pameran dan respon positif dari masyarakat yang merasa aman untuk mengkonsumsi produk saos dari UKM Sejahtera sentosa. Cukup jelas dalam Gambar tersebut terilaht kerumunan dalam protokol Covid, pembeli yang antusias "mengeroyok" saos Depika. Data disimpulkan bahwa antusiasme masyarakat kembali positif setelah program UKM Indonesia Bangkit ini dilaksanakan. Gambar 10 merupakan bukti penerimaan masyarakat terhadap produk saos UKM sejahtera sentosa yang disebar memalui media sosial. Kami meminta bantuan selebgram untuk promosi saos mitra. 


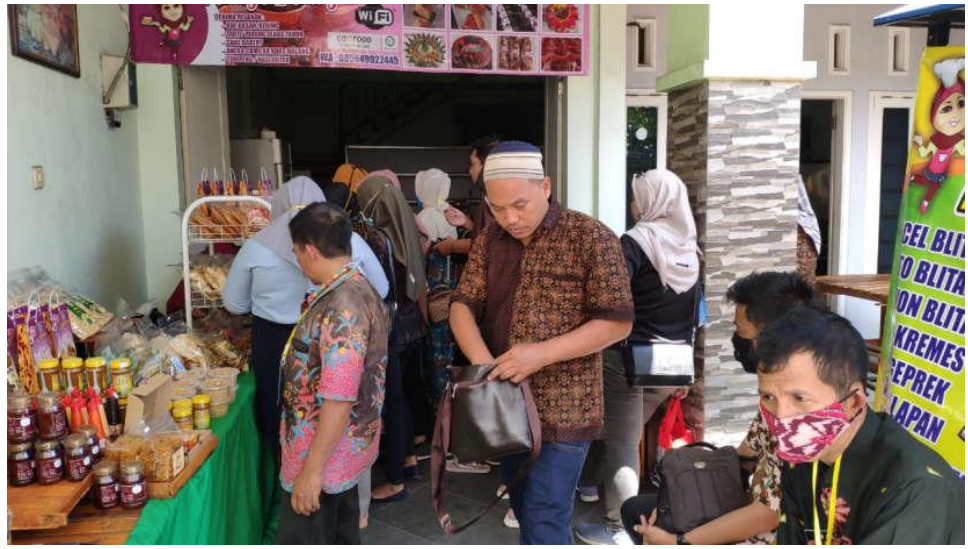

Gambar 9. Pameran penjualan saos

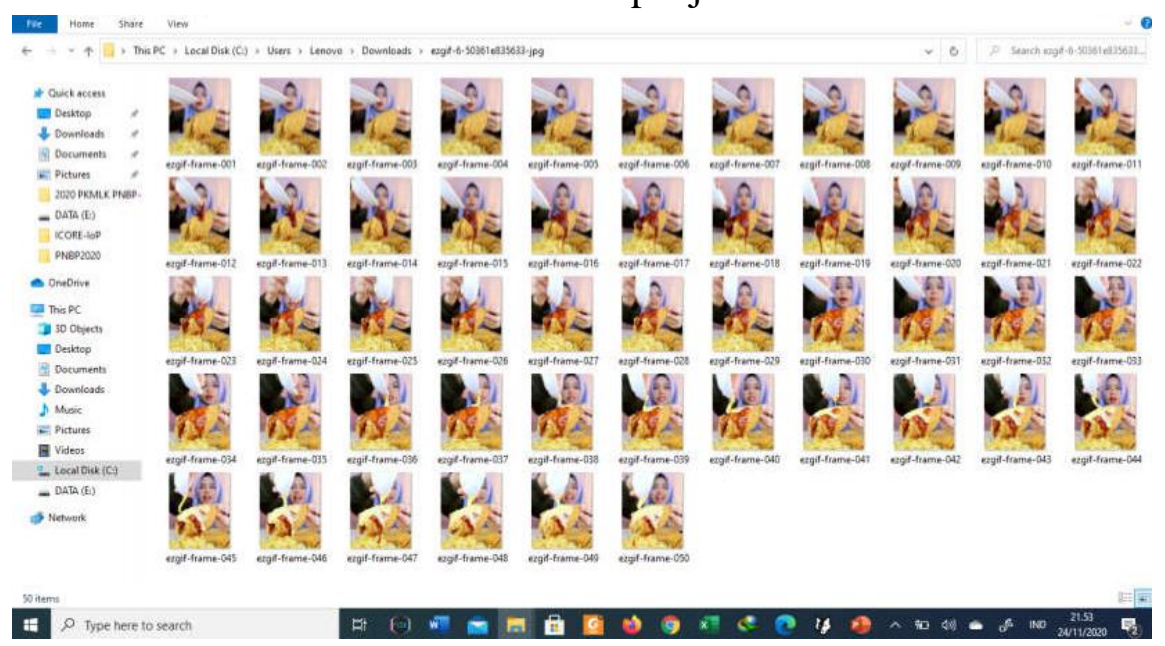

Gambar 10. Frame vidio promosi mitra melalui selebgram (vidio dikonversi ke frame gambar)

Kontribusi Mitra terhadap pelaksanaan Mitra sangat proaktif dalam membantu terutama ketika desain dan pengujian TTG produksi saos. Mitra juga telah berinisiasi untuk memperluas pasar dengan membuka toko di tokopedia dan shopie, termasuk promosi melalui selebgram yang populer di sekitas kota Malang dan kota Batu. Hal ini sangat membantu tim sementara smart apps dagang saos belum benar-benar $100 \%$ dapat digunakan.

\section{Analisis BEP}

Grafik kenaikan biaya produksi vs omzet penjualan ditunjukkan pada Gambar 11. Dari gambar tersebut dapat disimpulkan bahwa peningkatan biaya produksi yang timbul karena penggunaan teknologi manual lebih tinggi dibandingkan dengan penggunaan teknologi mesin, dilihat dari kenaikan kurva biaya produksi dengan teknologi mesin yang lebih landai. Namun, ada hal yang harus diperhatikan perusahaan apabila memutuskan untuk menggunakan teknologi mesin, antara lain sebagai berikut. 
a. Dalam kasus ini perusahaan belum memperhitungkan biaya pemeliharaan mesin, biaya penyusutan mesin, dan biaya-biaya lain yang berkaitan dengan mesin, karena teknologi mesin yang digunakan masih terbilang baru dan butuh banyak perbaikan.

b. Perusahaan tidak dianjurkan untuk terlalu memaksakan peningkatan omzet maupun profit dengan meningkatkan kapasitas produksi secara terus-menerus. Dikhawatirkan nantinya biaya produksi > omzet perusahaan, karena belum tentu target produksi (1200 botol saos) akan terjual seluruhnya.

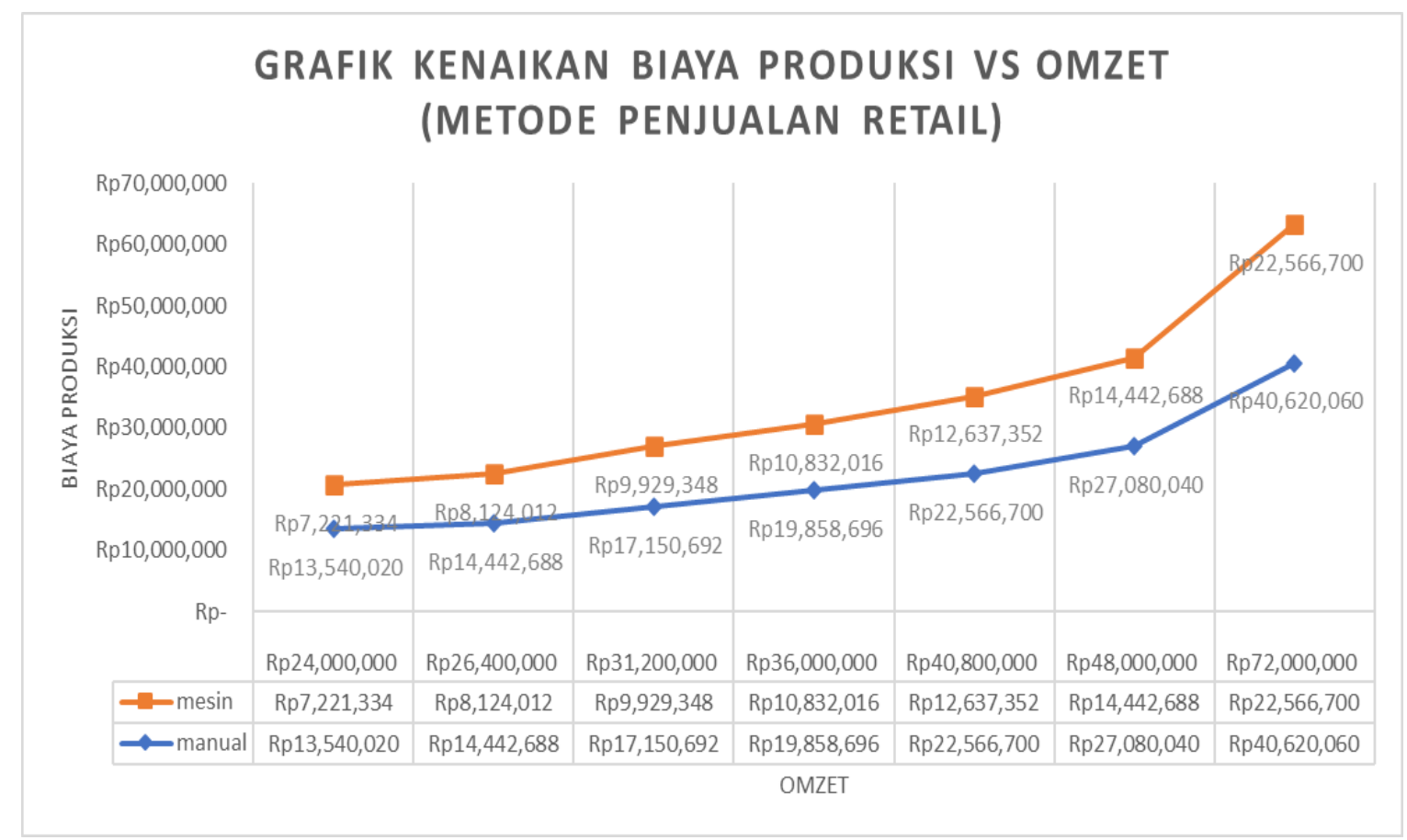

Gambar 11. Grafik kenaikan biaya produksi vs omzet

Hambatan di atas dapat diatasi dengan melakukan analisis Break Even Point (BEP). Analisis BEP sangat penting untuk dilakukan terutama bagi bisnis kecil / UMKM. Analisis BEP merupakan titik dimana jumlah biaya produksi sama dengan jumlah pendapatan yang diterima. Manfaat analisis BEP bagi bisnis kecil:

1. Menentukan tingkat penjualan minimal. Perusahaan dapat mengetahui berapa banyak unit yang harus diproduksi agar keuntungan yang didapatkan dapat menutup biaya produksi.

2. Pengendalian aktivitas produksi. Perusahaan dapat mengendalikan jumlah unit yang diproduksi, sehingga kegiatan produksi dapat berjalan secara efektif dan efisien (tidak ada unit produk yang terbuang, karena adanya kelebihan unit yang diproduksi).

Berdasarkan perhitungan BEP yang dilakukan Tim Pengabdian, UKM harus menjual 150 unit saos dan harus mendapatkan keuntungan sebesar Rp.3.000.000 dari 
penjualan saos, sehingga perusahaan tidak mengalami kerugian. Dengan analisis BEP, perusahaan dapat mengetahui berapa banyak unit yang harus diproduksi sehingga tidak ada produk saos yang akan terbuang / tidak laku terjual.

\section{Simpulan}

Kegiatan UKM Indonesia Bangkit 2020 yang menyasar mitra UKM lokal di kota malang yaitu UKM Sejahtera Sentosa telah berlangsung selama hampir 2 bulan. Ada beberapa kendala dalam pelaksanaan, namun semua dapat diatasi oleh Tim dan bantuan mahasiswa. Mitra sangat proaktif selam kegiatan ini. Mesin TTG saos sudah dioperasikan di mitra, termasuk pameran. Omzet mitra cukup signifikan mencapai $30 \%$ dari omzet terakhirnya. Hal ini dikarenakan adanya smart apps dagang saos yang memacu penjualan melalui digital marketing dan media sosial.

\section{Ucapan Terima Kasih}

Terima kasih kepada kementrian RISTEKBRIN yang telah mendanai kegiatan ini melalui skema pengabdian UKM Indonesia Bangkit 2020. 


\section{Daftar Rujukan}

Awaloedin, D. T., Sazali, Nurhilaludin, \& Hanifa, M. (2020). Strategi Menghadapi Dampak Pandemi covid 19 terhadap Usaha Kecil dan Menengah Dipa Teruna Awaloedin Sazali Nurhilaludin Muthia Hanifa. Manajemen.

Budiyanto, H., Tutuko, P., Winansih, E., Setiawan, A. B., \& Iqbal, M. (2020). Virtual expo menggunakan penggung tiup untuk umkm di kota malang sebagai solusi pameran online dimasa pandemi covid-19. Abdimas Universitas Merdeka Malang, December.

Irawati, W., Indrayani, L., \& Barli, H. (2020). Tata Kelola Keuangan Sederhana bagi UMKM di Kapuk Muara. Abdimasku : Jurnal Pengabdian Masyarakat, 3(3), 125. https://doi.org/10.33633/ja.v3i3.130

Komalasari, Y., Suryantari, E. P., Putu, N., \& Krismawintari, D. (2020). STRATEGI DIGITAL MARKETING BAGI UKM MENGHADAPI BADAI PANDEMI COVID19. November, 79-82.

Ridlo, M. R., Halawa, K., \& Harefa, S. I. P. (2020). Peranan Perpustakaan Perguruan Tinggi Dalam Mencegah Penyebaran Covid 19. Jurnal Tadwin, 1(1), 58-73. http://jurnal.radenfatah.ac.id/index.php/tadwin/article/view/5801

Rosmadi, M. L. N. (2020). Inovasi dan Kreativitas Pelaku Usaha UMKM di Era Covid19. Jurnal IKRA-ITH Ekonomika, 4(2), 87-94.

Sugiarti, Y., Sari, Y., \& Hadiyat, M. A. (2020). E-Commerce untuk Meningkatkan Daya Saing Usaha Mikro Kecil dan Menengah (UMKM) Sambal di Jawa Timur. Kumawula: Jurnal Pengabdian Kepada Masyarakat, 3(2), 298. https://doi.org/10.24198/kumawula.v3i2.28181

Sukur, moch halim. (2020). Penanganan Pelayanan Kesehatan Di Masa Pandemi Covid-19 Dalam Perspektif Hukum Kesehatan. Journal Inicio Legis Volume 1 Nomor 1 Oktober 2020, 1, 1-17.

Sunardi, Nardi. Lesmana, Rosa. Kartono. Rudy. Hasbiyah, W. (2020). Peran Manajemen Keuangan dan Digital Marketing dalam Upaya Peningkatan Omset Penjualan bagi Umkm Pasar Modern Intermoda Bsd City Kota Tangerang Selatan di Tengah Pandemi Covid-19. Abdi Masyarakat, 2(1), 75-86.

Thaha, A. F. (2020). Dampak Covid-19 Terhadap UMKM di Indonesia. Jurnal Brand, 2(1), 147-153.

Zanuar Rifai, \& Meiliana, D. (2020). Pendampingan Dan Penerapan Strategi Digital Marketing Bagi Umkm Terdampak Pandemi Covid-19. BERNAS: Jurnal Pengabdian Kepada Masyarakat, 1(4), 604-609. https://doi.org/10.31949/jb.v1i4.540 